\title{
ECONOMIC GROWTH: IMPACT OF LOCALLY-GENERATED REVENUE AND BALANCE FUNDS MODERATED BY CAPITAL EXPENDITURE
}

\author{
PERTUMBUHAN EKONOMI: DAMPAK PENDAPATAN \\ ASLI DAERAH DAN DANA PERIMBANGAN \\ DIMODERASI OLEH BELANJA MODAL
}

\author{
Novi Yanti ${ }^{1}$ dan Nurtati $^{2}$ \\ ${ }^{1,2}$ Sekolah Tinggi Ilmu Ekonomi Sumbar, Pariaman \\ Jl. Kolonel. Anas Malik By Pass Padusunan Pariaman, Indonesia \\ Telp. (0751) 4744973, HP. 085316853402 \\ E-mail noviyantizavi@gmail.com, nurtatistie@gmail.com
}

Naskah Masuk: :17-4-2020

Naskah Diterima: 18-5-2020

Naskah Disetujui: 3 -6-2020

\begin{abstract}
ABSTRAK
Pengalokasian anggaran pembangunan yang baik dapat mempercepat laju pertumbuhan ekonomi dalam pelaksanaan desentralisasi fiskal. Tata kelola pendapatan asli daerah dan dana perimbangan dapat meningkatkan pendapatanya melalui penggunaan belanja modal yang tepat, namun pertumbuhan ekonomi tidak selalu linear dengan sетиа sumber pendapatan tersebut. Tujuan penelitian adalah menganalisa pengaruh pendapatan asli daerah dan dana perimbangan meliputi dana bagi hasil, dana alokasi umum dan dana alokasi khusus secara parsial dan simultan terhadap belanja modal dan dampaknya terhadap pertumbuhan ekonomi. Metode penelitian adalah kuantitatif longitudinal research time series design. Penelitian dilakukan di Kabupaten/Kota Provinsi Sumatera Barat dengan data sekunder dari Badan Pusat Statistik Provinsi Sumatera Barat tahun 2009-2018. Analisis penelitian menggunakan uji regresi linear berganda dan path analysis. Hasil penelitian menunjukkan bahwa pendapatan asli daerah dan dana perimbangan yaitu dana alokasi umum dan dana alokasi khusus secara parsial dan simultan berpengaruh signfiikan terhadap belanja modal, namun dana bagi hasil secara parsial tidak berpengaruh signifikan terhadap belanja modal. pendapatan asli daerah dan dana perimbangan serta belanja modal secara parsial dan simultan berpengaruh signfiikan terhadap pertumbuhan ekonomi. Begitu juga belanja modal berpengaruh positif terhadap pertumbuhan ekonomi yang dimediasi oleh pendapatan asli daerah dan dana alokasi khusus, sedangkan belanja modal tidak berpengaruh signifikan terhadap pertumbuhan ekonomi yang dimediasi oleh dana alokasi umum dan dana bagi hasil. Kepala daerah kabupaten/kota Provinsi Sumatera Barat direkomendasikan membangun ketegasan perencanaan pembangunan daerah yang berimplikasi pada struktur alokasi belanja modal yang sesuai dengan tujuan dan sasaran masing-masing program pembangunan yang telah ditetapkan agar orientasi pertumbuhan ekonomi dapat berorientasi pada percepatan tingkat kesejahteraan masyarakat.
\end{abstract}

Kata Kunci: Pendapatan asli daerah, dana perimbangan, pertumbuhan ekonomi

\begin{abstract}
The allocation of development budget can accelerate the pace of economic growth in the implementation of fiscal decentralization. Through locally-generated revenue management and regional government, balance funds can increase their income through the use of appropriate capital expenditure however economic growth is not always linear with all sources of revenue. The purpose of this study is to analyze the effect of regional revenue and balance funds partially and simultaneously on capital expenditure and its impact on economic growth. The research method is quantitative with a longitudinal research timeseries design. The study was conducted in the Regency / City of West Sumatra Province with secondary data from the Central Statistics Agency in 2009-2018. Research analysis using multiple linear regression test and path analysis. The results showed that Locally-generated revenue, general, and special allocation fund partially and simultaneously have a significant effect on capital expenditure, but the profit-sharing
\end{abstract}

40 | Jurnal Pembangunan Nagari | Volume 5 Nomor 1 Edisi Juni 2020 : 40 - 54 
fund partially has no significant effect on capital expenditure. Locally-generated revenue, profit-sharing funds, general and special allocation fund, and capital expenditure partially and simultaneously have a significant effect on economic growth. Likewise, capital expenditure has a positive effect on economic growth which is mediated by locally-generated revenue and special allocation funds, while capital expenditure does not significantly influence economic growth mediated by general allocation funds and profit-sharing funds

Keywords: Locally-generated revenue, balance funds, economic growth

\section{INTRODUCTION}

Development oriented towards equitable development and its results, but the realization is not always the case in various economic policies undertaken by the government. It seems to be a belief that if economic growth continues spurred, the equitable development will gradually occur automatically. The role of regional development as an effort to equalize the economic growth and its results is still not much meaningful compared to sectoral development prioritizes increased production and productivity (Dang \& Pheng, 2015).

Over the past four decades, the prior concern of the world economic community has focused on ways to accelerate the growth of national income. Economists and politicians from all countries, both rich and poor countries, who adhere to a capitalist, socialist and mixed system are all very longings for and prioritizing economic growthoriented towards equitable development in each region (Shareia, 2015, Dang \& Pheng, 2015).

This effort can realize in improving the economic performance of the community under the existing potential in the area while still referring to national development goals. The implementation of regional planning needed sources of revenue is to support the implementation of regional development. In connection with economic growth, local governments required to be able to finance government activities by extracting the original wealth of the region in formulating good fiscal policy (Barata, 2019).

According to Law No. 33 of 2004, the source of revenue used for regional government funding in the implementation of fiscal decentralization is the Balance Funds, namely general and special allocation funds, profit-sharing funds, and other legal receipts. Through this acceptance, local governments must be able to increase their income to 
finance development activities in the economic field (Gamayuni, 2016). .

Although the authority has transferred to become an autonomous local government, the federal is still obliged to exercise control over the growth and prosperity of the area in aggregate affects the national economy. One indicator of the national economy and public welfare is the amount of income that can calculate it with the expenditure approach that explains that national income is a mathematical model: $\mathrm{Y}=\mathrm{C}+\mathrm{I}+\mathrm{G}+(\mathrm{X}-\mathrm{M})$.

Referring to the expected economy model is to grow along with the increase in the balance funds as a component of expenditure ("G") of the central government to the regions. However, the linearity between the accumulation of regional income funds and grant funds to economic growth can achieve if the area wisely plans and allocates existing funds for economic development projects as a catalyst for economic activity in the region.

The role of regional economic catalysts can be encouraged by increasing direct spending and reducing indirect expenditure that does not contribute to people's welfare. It worsened when corruption levels are high (d'Agostino, Dunne, \& Pieroni, 2016). But in reality, currently, the management of the local government budget in various regions is still ineffective. It caused by the allocation of personnel expenditure that continues to increase the contrary to the portion of capital expenditure for regional development continues to decrease. (Putri, 2016).

The program to increase infrastructure capital expenditure will directly affect the intensity of development, such as agricultural facilities, transportation, and other infrastructure that directly supports the productivity and welfare of the people. With the meaning of the infrastructure budget, the agriculture, health, and transportation sectors need to increase, while operational costs, official travel, or unproductive capital expenditure must be reduced (Burlon, 2017).

One way to measure economic performance is to measure the achievement of economic growth as an indicator. Economic growth will show the extent to which the government's performance in generating added value or community income in a certain period. Positive growth indicates an increased development and vice versa if non- 
positive means a decline in performance (Creel, Hubert, \& Labondance, 2015).

In a region often found differences in the growth rate between each area. Factors that cause differences in growth rates between regions is because each area has different potential resources. It means that regency that have abundant resources will be able to obtain high economic growth rates while it has few capitals such as Kab. Mentawai Kep and Kab. Pesisir Selatan will tend to get a low growth rate.

The rate of economic growth in the city of West Sumatra Province showed that the average city growth rate for the period 2009-2013 in West Sumatra was $6.17 \%$. The city has the highest economic growth rate is the Padang city. This city of is the Central City of the Province that has many sources of income so that the economic growth achieved is also high.

Based on these conditions, it can understand that between regency and cities, look at from the economic growth indicates an imbalance between the rate of economic growth in regency and cities. In general, the imbalance caused by the number of resources and income owned by an area. Regional income sourced from the Regional Revenue and
Balance Funds include Profit sharing funds, General Allocation Funds, and Special Allocation Funds.

Because of these differences in capacity, local governments must be able to draw up regional development plans that have implications for the development goals and targets that have set so that the allocation of regional income and capital expenditure has a positive impact on economic growth. For this reason, this research aims to analyze first. Is there any influence from the locally-generated revenue and the balance funds of general allocation fund, special allocation fund, and profitsharing fund towards capital expenditure? Second, is there any influence of locally-generated income, general allocation fund, special allocation fund, profit-sharing fund, and capital expenditure on economic growth? Third, does capital expenditure mediate the relationship between locallygenerated revenue, general allocation funds, special allocation funds, and profit-sharing funds on regional economic growth?

\section{METHOD}

The research method uses a quantitative research approach to the longitudinal research method with a time 
series design that is carried out intensively, in detail, and depth (Hartwell, 2017). This research conducted in the Regency/ City of West Sumatra Province. This study used secondary data from the Central Statistics Agency in 2009-2018. As an illustration, the method designed in this study can describe in the following conceptual framework:

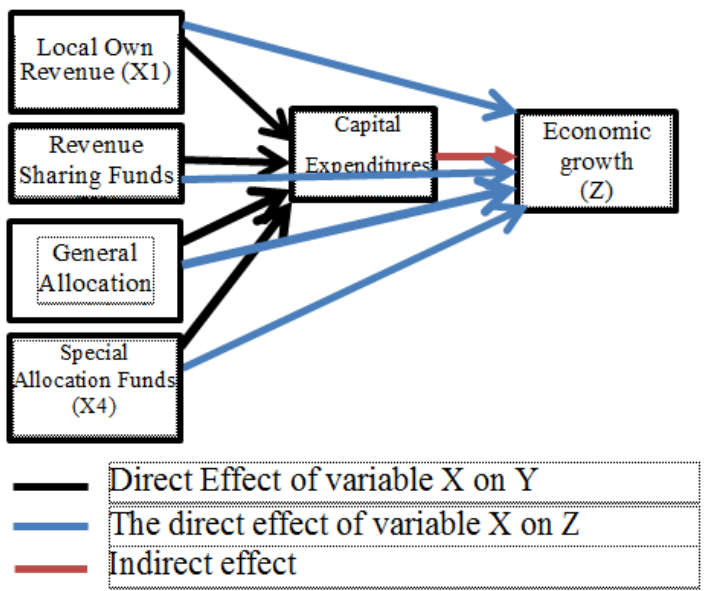

Figure 1. Research Conceptual Framework

The research analysis is descriptive analysis and inferential analysis. It intended to provide a preliminary description of the balanced fund locally-generated revenue, general allocation funds, special allocation funds, capital expenditure, and economic growth. Statistical analysis of inference carried out using multiple linear regression and path analysis. (Loehlin \& Beaujean, 2016).
Path analysis is a technique for analyzing cause and effect relationships that occur in multiple linear regression, if the independent variables affect the dependent variable not only directly, but also indirectly. For more details, the following is a regression model in this study that developed into three models, namely:

I $\mathrm{Y}=\alpha_{1}+\beta_{1} \mathrm{LGR}+\gamma_{1} \mathrm{PSF}+\gamma_{1}$

$\mathrm{GAF}+\delta_{1} \mathrm{SAF}+\varepsilon$ (Direct Effect)

II $\mathrm{Y}=\alpha_{1}+\beta_{1} \mathrm{LGR}+\gamma_{1} \mathrm{PSF}+\gamma_{1} \mathrm{GAF}$

$+\delta_{1} \mathrm{SAF}+\delta_{1} \mathrm{CE}+\varepsilon$ (Direct Effect)

III $Z=\alpha+\beta_{1} X_{1}+\beta_{2} X_{2}+\beta_{3} X_{3}+\beta_{4} X_{4}$

$+|\mathrm{e}|=\alpha+\beta 7 \mathrm{Y} \quad$ (Indirect Effect)

\section{RESULTS AND DISCUSSION}

Following the research objectives stated in the introduction, First, analyzing the effect of locally-generated revenue and balance fundss of general allocation funds, special allocation funds, and profit-sharing on capital expenditure. Second, to analyze the locally-generated income effect, general and special allocation funds, profitsharing funds, and capital expenditure on economic growth. Third, analyzing the capital expenditures as a mediator variable the relationship between locallygenerated revenue, general allocation funds, special allocation funds, and 
profit-sharing funds that have an impact on regional economic growth.

\section{Direct effect of LGR and Capital Expenditure (First Equation Model)}

From the results of inferential statistical tests using multiple linear regressions in the first regression model is obtained as in the following table:

Table 1. Regression of the First Equation Model

\begin{tabular}{|c|c|c|c|c|c|}
\hline \multirow[b]{2}{*}{ Model } & \multicolumn{2}{|c|}{$\begin{array}{l}\text { Unstandardized } \\
\text { Coefficients }\end{array}$} & \multirow{2}{*}{$\begin{array}{c}\begin{array}{c}\text { Standar } \\
\text { diCoeffi } \\
\text { cien }\end{array} \\
\text { Beta }\end{array}$} & \multirow[b]{2}{*}{$\mathrm{t}$} & \multirow[b]{2}{*}{ Sig. } \\
\hline & B & $\begin{array}{l}\text { Std. } \\
\text { Error }\end{array}$ & & & \\
\hline 1 (Constant) & $3.565 \mathrm{E} 1$ & $1.033 \mathrm{E} 1$ & & 3,453 & .001 \\
\hline LGR (X1) & .221 & .070 & .206 & 3,144 & .002 \\
\hline PSF (X2) & .105 & .202 & .025 & .517 & 606 \\
\hline GAF (X3) & 108 & .030 & .281 & 3,558 & .001 \\
\hline SAF(X4) & .561 & .070 & 492 & 7,979 & .000 \\
\hline
\end{tabular}

The result analysis of locallygenerated revenue data and balance fundss of general and special allocation funds partially have a direct positive effect on capital expenditure. It has a significant value of sig $>0.05$. For profitsharing funds indicating there is an indirect effect between it to capital expenditure with a significant of $>0.005$, this is 0.606. It is due to several reasons including 1) The possibility of achievement of Profit-sharing funds in most Regencies / Cities in West Sumatra Province, their contribution to the allocation of Capital Expenditures is still little, 2) The possibility of profit-sharing fund obtained is more dominated by the Tax Sharing Funds, whose income is not too provides a significant contribution to capital expenditure compared to regional natural resource profit-sharing funds,

While simultaneous locallygenerated revenue, general allocation funds, special allocation funds, and profit-sharing funds show a significant effect on capital expenditure as can be seen in table 2 below:

Table 2. Feasibility Model First

\begin{tabular}{|c|c|c|c|c|c|}
\hline \multicolumn{6}{|c|}{ ANOVAb } \\
\hline Model & $\begin{array}{l}\text { Sum of } \\
\text { Squares }\end{array}$ & Df & $\begin{array}{l}\text { Mean } \\
\text { Square }\end{array}$ & $\mathrm{F}$ & Sig. \\
\hline $\begin{array}{l}\text { Regressi } \\
\text { on }\end{array}$ & $6.266 \mathrm{E} 23$ & 4 & $1.566 \mathrm{E} 23$ & 102,283 & .000 \\
\hline Residual & 2.251E23 & 147 & $1.531 \mathrm{E} 21$ & & \\
\hline Total & 8.517E23 & 151 & & & \\
\hline
\end{tabular}

Based on Table 2 above, it showed that the calculated F-value of 102.293 with a significant value of 0.000 $<0.05$, this result can be concluded that the locally-generated revenue, profitsharing funds, general and special allocation fund simultaneously influence the capital expenditure allocation.

\section{Indirect effect of LGRF and Balance fundss on Economic Growth (Second Equation Model).}

Inferential statistical tests with multiple linear were regression obtained the following results: 
Table 3. Regression Equations for the Second Model

\begin{tabular}{|c|c|c|c|c|c|c|}
\hline \multirow{2}{*}{\multicolumn{2}{|c|}{ Model }} & \multicolumn{2}{|c|}{$\begin{array}{l}\text { Unstandardized } \\
\text { Coefficients }\end{array}$} & \multirow{2}{*}{$\begin{array}{c}\begin{array}{c}\text { Standa } \\
\text { rdiCoef } \\
\text { ficien }\end{array} \\
\text { Beta }\end{array}$} & \multirow[b]{2}{*}{$\mathrm{T}$} & \multirow[b]{2}{*}{ Sig. } \\
\hline & & B & $\begin{array}{l}\text { Std. } \\
\text { Error }\end{array}$ & & & \\
\hline \multirow[t]{6}{*}{1} & (Constant) & 2.955E1 & 2.597E1 & & 11,377 & .000 \\
\hline & LGR (X1) & 23,774 & 1,760 & .515 & 13.509 & .000 \\
\hline & PSF (X2) & 57,475 & 4,899 & .325 & 11,732 & .000 \\
\hline & GAF (X3) & 8,327 & .764 & .506 & 10,905 & .000 \\
\hline & SAF(X4) & 7,495 & 2,035 & .153 & 3,684 & .000 \\
\hline & CE (Y) & 6,349 & 1995 & .148 & 3,182 & .002 \\
\hline
\end{tabular}

Based on table 3 above, it can explain that locally-generated revenue and balance fundss include profit-sharing funds, general and special allocation funds, and capital expenditure partially has a direct positive. The effect of revenue sharing funds on economic growth is $57.47 \%$. This estimation showed that balance fundss always increase. It means the local government can carry out the development programs well. Here, all regional governments focus on developing infrastructure. The government can get more equal balance fundss (profit-sharing funds) due to the government's successful reporting of blood funds annually on time. Obtaining the total of special allocation funds will directly affect economic growth. If the special allocation fund shows a positive number, the use of these funds has succeeded in stimulating the regional economy, meaning that tax collection has no impact on the economic survival of small communities.

Rakhyadi, who stated that there is an influence of the Profit-sharing funds on economic growth. (Rakhyadi, 2019) Meanwhile, simultaneous locallygenerated revenue, general and special allocation funds, profit-sharing funds, and capital expenditure simultaneously also show a significant effect on economic growth can look at in Table 4 below.

Table 4. Feasibility of the Second Model

\begin{tabular}{|c|c|c|c|c|c|}
\hline \multicolumn{6}{|c|}{ ANOVA $^{b}$} \\
\hline Model & $\begin{array}{l}\text { Sum of } \\
\text { Squares }\end{array}$ & Df & $\begin{array}{l}\text { Mean } \\
\text { Square }\end{array}$ & $\mathrm{F}$ & Sig. \\
\hline $\begin{array}{l}1 \text { Regres } \\
\text { sion }\end{array}$ & $1.436 \mathrm{E} 27$ & 5 & $2,872 \mathrm{E} 26$ & 320,56 & $.000 a$ \\
\hline Residual & $1,308 \mathrm{E} 26$ & 146 & $8.960 \mathrm{E} 23$ & & \\
\hline Total & $1.567 \mathrm{E} 27$ & 151 & & & \\
\hline
\end{tabular}

Based on Table 4 shows that the calculated $F$ value of 102.293 with a significant of $0,000<0.05$, this result can be concluded that locally-generated revenue, profit-sharing funds, general and special allocation funds, and capital expenditures simultaneously affect economic growth.

Indirect effect of CE mediated by LGR and PSF, GAF, SAF on Regional Economic Growth (Third Model Equation).

From the results of data processing in the two regression models 
that have carried out, obtained the path analysis scheme with the magnitude of the value of $\mathrm{e} 1=\sqrt{1-0.736}=0.514$ and value of e $2=\sqrt{1-0.917}=0.288$ with the path analysis model scheme as follows:

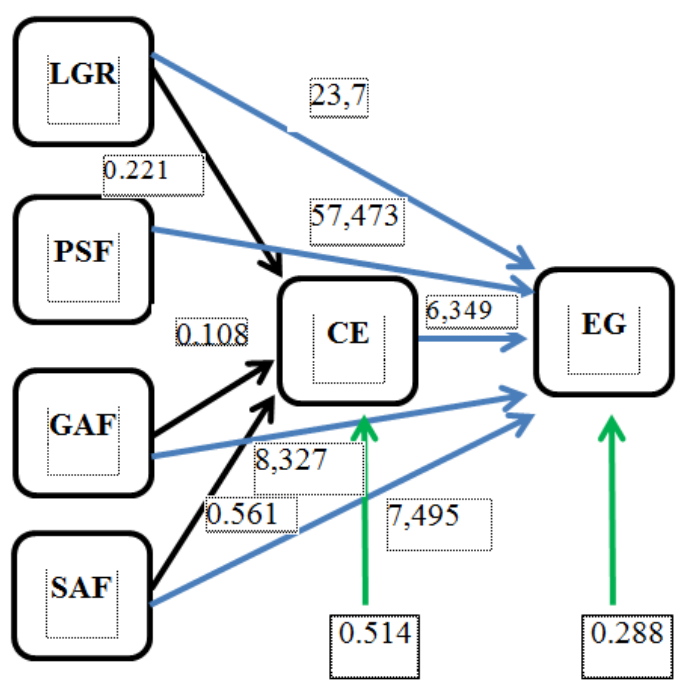

Figure 2 . Analysis of Variable LGR, PSF, GAF, and SAF Variable Path Analysis of Economic Growth with Capital Expenditures as Intervening Variables

Based on the analysis of the path analysis between model 1 and model two above, it can be formulated multiple linear regression equations in each model as follows:

Model Equation 1

$\mathrm{Y} 1=3.565 \mathrm{E} 10+0.221 \mathrm{LGR}+0.105 \mathrm{PSF}+$ $0.108 \mathrm{GAF}+0.561 \mathrm{SAF}+0.514$

Model Equation 2

$\mathrm{Y} 2=2.955 \mathrm{E} 12+23,774 \mathrm{LGR}+57,475 \mathrm{PSF}+$

$8,237 \mathrm{GAF}+7,4951 \mathrm{SAF}+6,349 \mathrm{CE}+0.288$

Model Equation 3
Path Analysis of the Effect of LocallyGenerated Revenue (LGR) to Economic Growth (EG) with Capital Expenditure (CE) as an intervening variable.

To calculate whether the Regional Revenue variable has a significant effect on economic growth mediated by Capital Expenditures (CE), it can describe as follows:

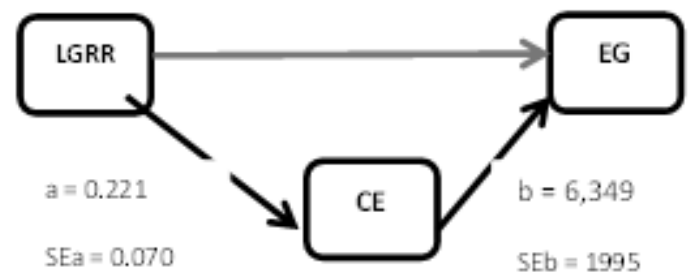

Figure 3. Path Analysis of LGR Direct Effect on Capital Expenditures and Its Impact on Economic Growth (Indirect Effect)

The indirect effect of Locallygenerated revenue (LGR) on Economic Growth (EG) with Capital Expenditure (CE) as an intervening variable calculated by multiplying the LGR pathway to capital expenditure: (a) and capital expenditure on economic growth (b) or ab. The magnitude of the indirect effect in this variable is as follows

$$
a b=(0.221) \times 6.379=1.403
$$

In addition to calculating the $a b$ value, in the indirect effect test, it is necessary to calculate the standard error of the indirect effect or sat. The amount of Sat in this variable is as follows:

$$
\begin{aligned}
\text { Sat }=\sqrt{b^{2} S a^{2}+a^{2} S b^{2}+S a^{2} S b^{2}} \\
\text { Sat }=\sqrt{0.417048} \\
\text { Sat }=0.6458
\end{aligned}
$$


To test the significance of the indirect effect it is necessary to calculate the $\mathrm{t}$ value of the $a b$ coefficient as follows:

$$
\begin{aligned}
& \mathrm{t}=\frac{\mathrm{ab}}{s a b} \\
& =\frac{1,403}{0.6458} \\
& =2.172699
\end{aligned}
$$

To find out whether the intervening variable has a significant effect can be compared to the findings of the calculated t-value of the coefficient $a b$ compared with the value of t-table. From the analysis, it can obtain that the ttable is 1.97623 . Based on this t of the $a b$ coefficient of $2.172699>\mathrm{t}$ table 1.97623 , the intervening can said to have a significant effect on economic growth

The locally-generated revenue can derive from taxes, retirement, and the natural resources of the region itself allocated to finance regional development. It means that the local government has succeeded in increasing locally-generated revenue activities from the tax and retribution sector. The government has succeeded in increasing the regional economic potential has the prospect of driving the pace of direct economic growth affects capital expenditure and economic growth. The local government succeeds in carrying out regional development programs based on regional economic prospects where the Regional Government succeeded in allocating Capital Expenditure following the potential economic prospective also has a significant effect indirectly on economic growth mediated by capital expenditure. Increasing GRDP, the rate of economic growth will increase government revenue from local taxes as the primary source of locally-generated income. Furthermore, the increase in government revenue will encourage an increase in government services to the community, which in turn expected to increase community productivity, which in turn can improve economic growth again and vice versa. The economic growth and communities per capita income will encourage the ability of the community to pay taxes and other retirement fees that affect the increase in capital expenditure to finance the prospects of potential regional development that can boost the rate of economic growth in the next period (Zafar, Shahbaz, Hou, \& Sinha, 2019). Research results supported by research Hermawati in the Regency/City of Kalimantan Province that there is an 
influence of capital expenditure on economic growth (Hermawati, 2018)

Path Analysis of the Effect of ProfitSharing Funds (PSF) on Economic Growth (EG)

From the form of the relationship analysis of the influence of the Profit Sharing Fund on Capital, Expenditures do not have a significant effect where the t-value obtained is small from the t-table value of $0.517<1.97623$ and the value of sig. 0.606>0.05, so it can conclude that PSF partially has no direct positive effect on capital expenditure.

Even, This PSF directly has a significant effect on Economic Growth with a t-value of $11.732>1.97623$, the value of sig. $0,000<0.05$. Because the first model has no significant effect, the intervening variable cannot be measured. It means that it is clear that there is no significant effect of an intervening variable on capital expenditure on economic growth analyzed from the Sharing Fund variable.

The results of this study differ from studies Wiraswasta et al who reported that profit-sharing funds indirectly affect economic growth mediated by capital expenditure in the cities of East Java Region in 2009-2014

(Wraswasta, Pudjihardjo, \& Adis, 2019)

Effect of General Allocation Funds (GAF) on Economic Growth (EG) with Capital Expenditure (CE) as an intervening variable.

The following is an analysis of the effect of the variable General Allocation Funds on economic growth mediated by Capital Expenditures (BM) with the following measurement stages:

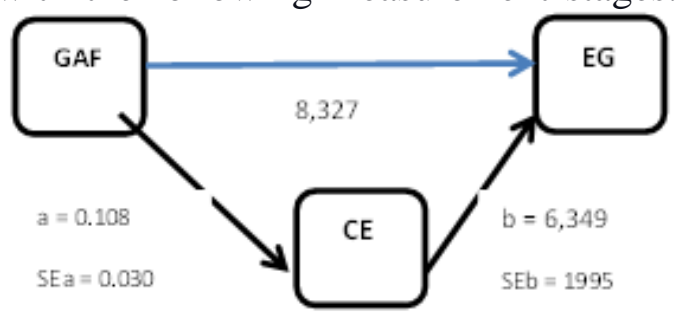

Figure 4. The indirect effect of the General Allocation Fund on Capital Expenditures and their Impact on Economic Growth.

The indirect effect of the General Allocation Fund on Economic Growth with capital expenditure as an intervening variable is calculated by multiplying the general allocation fund channel on capital expenditure (a) and capital expenditure on economic growth (b) or ab. The magnitude of the indirect effect in this variable is as follows:

$$
\mathrm{ab}=(0.108) \times 6.379=0.685692
$$

In addition to calculating the $a b$ value, in the indirect effect test, it is necessary to calculate the standard error of the indirect effect or sat. The amount of Sat in this variable is as follows:

Sat $=\sqrt{b^{2} S a^{2}+a^{2} S b^{2}+S a^{2} S b^{2}}$ 


$$
\begin{aligned}
& \text { Sat }=\sqrt{0.08732} \\
& \text { Sat }=0.93445
\end{aligned}
$$

To test the significance of the indirect effect it is necessary to calculate the $t$ value of the $a b$ coefficient as follows:

$$
\begin{aligned}
& \mathrm{t}=\frac{\mathrm{ab}}{s a b} \\
& =\frac{0.68592}{0.93445} \\
& =0.733792
\end{aligned}
$$

From these results of the research can look at that the intervening variable does not have a significant effect on economic growth. It because compared between the findings of the calculated tvalue of the coefficient $a b$ compared with the value of t-table, the results of the $t$ value are smaller than the t-table is $0.733792<1.97623$ where the value of sig. $0,000>0.05$. Therefore it can be concluded that the intervening coefficient does not significantly influence economic growth.

The results of this study are supported by research findings Wiraswasta et al reported that indirectly general allocation funds affect economic growth mediated by capital expenditure in East Java Region in 2009-2014 (Wraswasta, Pudjihardjo, \& Adis, 2019).

In the theory of regional finance, the funds allocated to local governments are balanced. Balance fundss are funds allocated to meet regional needs that are specific, such as infrastructure development or regional growth support facilities. The Purpose is for community welfare. It also eliminates the fiscal gap. This gap in government economic conditions can change by changing government revenues and expenditures) between the central government and regional governments, to carry out decentralization from the central government for the implementation of local autonomy, and to increase efficiency and effectiveness in implementing regional autonomy (Karianga, 2016).

The general allocation funds get from the central government to the regions based on decentralization. The general allocation fund itself allocated for financing in optimizing the potential of an area. (Yulihantini \& Wardayati, 2017).

The general allocation fund shows a number of economic growth, which means that the allocation of it allocated to budget expenditure and government work programs have succeeded in increasing economic growth in a region. Besides, the allocation of general funds allocated for capital expenditure has succeeded in 
influencing the efficiency of capital expenditure in a region, although indirectly does not significantly influence economic growth, this is likely due to (a) Due to the allocation of general allocation funds for government development work programs not evenly distributed in all regency/city areas Prov. West Sumatra (b) Due to some regions experiencing fluctuations in the growth rate of general allocation funds which tend to be negative. (Fahlevi \& Kurniawan, 2017)

Effect of Special Allocation Funds (SAF) on Economic Growth (EG) with Capital Expenditure (CE) as an intervening variable.

The effect analysis of the variable General Allocation Funds on Economic Growth mediated by Capital Expenditures with the following measurement stages:

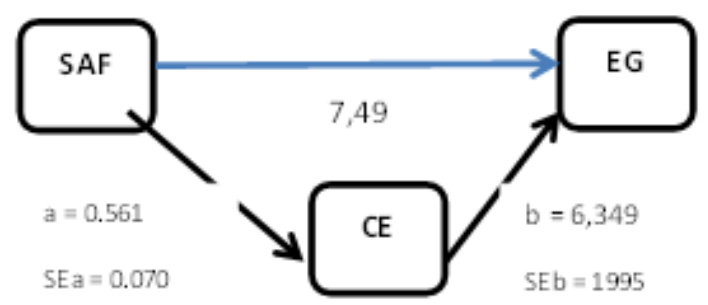

Figure 5. Indirect Effects of Special Allocation Funds on Capital Expenditures and Their Impacts on Economic Growth (Indirect Effects)

The indirect effect of the Special Allocation Fund on Economic Growth with capital expenditure as an intervening variable is calculated by multiplying the general allocation fund channel on capital expenditure (a) and capital expenditure on economic growth (b) or ab. The magnitude of the indirect effect in this variable is as follows:

$\mathrm{ab}=(0.561) \times 6.379=3.578619$

In addition to calculating the $a b$ value, in the indirect effect test, it is necessary to calculate the standard error of the indirect effect or sat. The amount of Sat in this variable is as follows:

$$
\begin{gathered}
\text { Sat }=\sqrt{b^{2} S a^{2}+a^{2} S b^{2}+S a^{2} S b^{2}} \\
\text { Sat }=\sqrt{1.475257} \\
\text { Sat }=1.2146
\end{gathered}
$$

To test the significance of the indirect effect it is necessary to calculate the $t$ value of the $a b$ coefficient as follows:

$\mathrm{t}=\underline{\mathrm{ab}}$

$s a b$

$$
=\frac{3.561789}{1.2146}
$$

$=2.932479$

From these results it can be seen that the intervening variable has a significant effect because when compared between the findings of the calculated $\mathrm{t}$ value of the coefficient $a b$ with the value of $t$ table, the calculated value of $t$ is greater than $t$ table of $2.932479>1.97623$ where the value of sig. $0,000>0.05$. Therefore it can be concluded that the intervening coefficient 
has a significant effect on economic growth.

The results of this study differ from studies Wiraswasta et al reported that the special allocation fund indirectly influenced economic growth mediated by capital expenditure in East Java Region in 2009-2014. (Wiraswasta et al., 2019).

Special allocation funds are funds that are allocated specifically for a regional urgency like the need for facilities and infrastructure. Therefore, special allocation funds are usually more specifically for the development of facilities and infrastructure that can support the rate of economic growth in regional fiscal policy. It means that the local government has succeeded in implementing all the programs that have been disbursed by the central government to develop the region through fiscal decentralization policies that contribute to regional economic growth. The success of implementing the development program following the provisions of the federal government program, the acquisition of balance fundss in the next period will increase. Increasing the special allocation fund means that there is an increase also directly in capital expenditure. (Mutiah, 2015).
The results of this study are the same as the research Wiraswasta et al reported that the special allocation fund indirectly influenced economic growth mediated by capital expenditure in East Java Region in 2009-2014 (Wiraswasta et al., 2019).

\section{RECOMMENDATION}

The results show that locallygenerated revenue and balance fundss positively and significantly affect capital expenditure and economic growth directly. However, it is only indirectly locally-generated revenue and special allocation funds that have a significant impact on economic growth mediated by capital expenditures.

This condition shows that the Regency / City Regional Government of West Sumatra Province has had to reduce the level of financial dependence on the Central Government and try to be independent in financing development through the increase in the original income of the region. Another step that must stabilize is to increase the rate of economic growth by making West Sumatera Province an attractive area for investment.

This strategy can attract investment to the regions. It is possible to do with several steps. First, providing 
facilities of capital and industrial activities license. Second, ensuring continuity of industrial raw material supplies, Third, providing security for local entrepreneurs investing in the region, fourth, given tax holiday for the new local prospective industry both private and public industry, for the example given local free-tax during one or two years.

\section{CONCLUSION}

From the results of the study and discussion, it can conclude that the Locally-generated revenue, General and Special Allocation Fund partially and simultaneously have a significant effect on Capital Expenditures. While the Proofing Revenue Fund Partially does not affect Capital Expenditure. Likewise, with LGR, profit-sharing funds, general and special allocation funds, and capital expenditure partially and simultaneously have a significant effect on Economic Growth.

The impact of economic growth indirectly mediated by the Locallygenerated revenue and special allocation funds, but capital expenditure indirectly does not have a significant effect on economic growth mediated by the general allocation fund and profit-sharing funds.

\section{ACKNOWLEDGMENTS}

This study supported by STIE Sumbar Pariaman. We thanks so much to LP3ESIDA was funded this research and Reflianto, M.Pd who help us in the particular technique, methodology, and comments for a great improvement of this paper

\section{REFERENCES}

Barata, A. (2019). Strengthening National Economic Growth And Equitable Income Through Sharia Digital Economy In Indonesia. Journal of Islamic Monetary Economics and Finance, 5(1), 145168.

Burlon, L. (2017). Public expenditure distribution, voting, and growth. Journal of Public Economic Theory, 19(4), 789-810.

Creel, J., Hubert, P., \& Labondance, F. (2015). Financial stability and economic performance. Economic Modelling, 48, 25-40.

d'Agostino, G., Dunne, J. P., \& Pieroni, L. (2016). Government spending, corruption and economic growth. World Development, 84, 190-205.

Dang, G., \& Pheng, L. S. (2015). Theories of economic development. In Infrastructure investments in developing economies (pp. 11-26). Springer.

Fahlevi, h., \& kurniawan, y. (2017). Revenue budget variance and capital expenditure spending: empirical evidence from indonesian local governments.

Gamayuni, R. R. (2016). The effect of local government characteristics and the examination result of Indonesian supreme audit institution on economic growth, with financial performance as intervening variable 
in district and city government of lampung province. Research Journal of Finance and Accounting, 7(18), 119-136.

Hartwell, R. M. (2017). The industrial revolution and economic growth (Vol. 4). Taylor \& Francis.

Hermawati, W. (2018). Pengaruh Belanja Modal terhadap Pertumbuhan Ekonomi pada Kabupaten/Kota di Provinsi Kalimantan Utara. Universitas Terbuka.

Karianga, H. (2016). New Paradigm for Local Financial Management: A Review of Local Budgeting System. Hasanuddin Law Review, 2(3), 398408.

Loehlin, J. C., \& Beaujean, A. A. (2016). Latent variable models: An introduction to factor, path, and structural equation analysis. Taylor $\&$ Francis.

Mutiah, R. M. (2015). The Effect of Surplus Budget Financing, Special Allocation Fund, General Allocation Fund, Regional Revenue, and Characteristics of Local Government on Decision of Capital Expenditure (Survey in Local Government in Indonesia). Research Journal of Finance and Accounting, ISSN, 1697-2222.

Putri, F. A. I. (2016). Analisis Pengaruh Belanja Modal Dan Aset Daerah Terhadap Pertumbuhan Ekonomi Di Kota Pasuruan Tahun 2005-
2015. University of Muhammadiyah Malang.

Rakhyadi, R. (2019). Pengaruh Pendapatan Asli Daerah, Dana Alokasi Umum, Dana Alokasi Khusus, Dan Dana Bagi Hasil Terhadap Pertumbuhan Ekonomi Di Provinsi Aceh. Universitas Pembangunan Nasional Veteran Yogyakarta.

Shareia, B. F. (2015). Theories of development. International Journal of Language and Linguistics, 2(1), 78-90.

Wiraswasta, F., Pudjihardjo, M., \& Adis, P. M. (2019). Pengaruh Dana Perimbangan Dan Pendapatan Asli Daerah (Pad) Terhadap Pertumbuhan Ekonomi Melalui Belanja Modal Di Kota Dalam Wilayah Jawa Timur (Tahun 20092014). Jurnal Bisnis Dan Manajemen, 5(2).

Yulihantini, D. T., \& Wardayati, S. M. (2017). Financial accountability in the management of village fund allocation.

Zafar, M. W., Shahbaz, M., Hou, F., \& Sinha, A. (2019). From nonrenewable to renewable energy and its impact on economic growth: the role of research \& development expenditures in Asia-Pacific Economic Cooperation countries. Journal of Cleaner Production, 212, 1166-1178. 